https://doi.org/10.18485/iipe_60nam.2021.ch1

\title{
THE EVOLUTION OF THE NAM'S ROLE IN WORLD AFFAIRS DURING THE COLD WAR DECADES
}

\author{
Jovan ČAVOŠKI ${ }^{1}$
}

\begin{abstract}
This chapter deals with the evolution of the international role of the NAM during the Cold War years, a historical period when the movement's influence was at its apex and its worldwide presence was fully recognised and embraced by both great powers and small countries. The strategic choice of non-alignment, boasting its strong non-bloc credentials and independent streak, had evolved from a loose non-aligned group of the 1960s, which brought together a number of countries on a more ad hoc basis, into a fully-fledged and permanent international organisation that, through overwhelming numbers of its member states and a well-defined global agenda, succeeded in securing the place right at the very centre of world affairs during the 1970s. In many ways, the NAM had become the third pole of international relations during those decades, one aspiring to represent the interests and needs of the world standing between the two blocs while also seeking corresponding advantages in strengthening its individual and collective security and propelling its economic prosperity. Along this arduous path, the NAM would experience many ups and downs, nonetheless, acquiring a more positive and lasting legacy than not. Key words: non-alignment, the NAM's evolution, the Cold War, security, development.
\end{abstract}

\section{Introduction}

The Non-Aligned Movement (NAM), officially established at the 1970 Lusaka Conference, also preceded by a less formal non-aligned group which

\footnotetext{
${ }^{1}$ Research Fellow, Institute for Recent History of Serbia, Belgrade.

E-mail: jcavoski@yahoo.com.

This research was supported by the Science Fund of the Republic of Serbia, PROMIS, \#6062589, YEH.
} 
had launched its global presence at the 1961 Belgrade Conference, represents one of the significant global political phenomena emerging in the past 60 years - an international organisation encompassing four different continents and the majority of the United Nations (UN) members (120 nowadays), a strong voice of the post-colonial and non-bloc world since 1945, a byproduct of the East-West conflict of the 1950s and 1960s and a chief protagonist of the North-South conflict of the 1970s and 1980s. On the other hand, the NAM remains one of the major institutional relics of the Cold War today, still very much active and present in world affairs, though with a somewhat diminished global role and influence as compared to the heyday years of the 1960s and 1970s, but, nonetheless, one of the relevant institutional instruments through which the Third World, i.e. Global South, still exercises a tangible collective role in international politics in general and inside the UN in particular. In many ways, these strivings for setting up a non-great power alternative inside the dominant Cold War bipolar structure, as it was the case with the NAM, were primarily driven by a long-standing desire of many lesser powers to launch a comprehensive political and economic overhaul of the existing world order, one that would be ultimately more in line with the needs and aspirations of the post-colonial, non-bloc, and developing nations. On the other hand, what has remained as one of the remarkable features of the NAM, both during the Cold War decades and afterwards, was its significant capacity to, as far as it was possible and not without certain contradictions, absorb and level out many of the outstanding geographical, historical, cultural, religious, political, social, and economic differences between its member states, thus gradually transforming them into an independent collective actor in world affairs, one dedicated to pursuing key global issues, primarily the ones pertaining to the preservation of sovereignty, strengthening of regional and global security, as well as boosting the balanced socio-economic development of the underdeveloped part of the world. However, what really constituted the essential criteria of being a genuinely non-aligned country and becoming a full-NAM member afterwards was the non-bloc character of its international stance, irrespective of all the above-mentioned specific differences.

This article will follow the evolution of the non-aligned group and the subsequent NAM through four distinct phases. The first phase was the one related to the emergence of the non-aligned group in the late 1950s and early 1960s and the convening of the Belgrade Conference, which was the very first non-aligned summit in history and the starting point for the process of the gradual establishment of the movement. The second phase was marked by confrontation and crisis plaguing the non-aligned group, personified in 
the struggle for international recognition with the competing Afro-Asian group, especially during the 1964 Cairo Conference, after which the nonaligned group had entered into a protracted crisis until the late 1960s when no major non-aligned events were convened. The central part would be dedicated to the third phase, one encompassing most of the 1970s, the apex years of its global influence, when the NAM was officially established and its general orientation was directed towards the creation of a new world political and especially economic order, thus putting the movement at the very centre of the North-South conflict. The last phase of this period was related to the NAM's protracted internal crisis and rapid decline, mostly coinciding with the end of the Cold War, when the movement, despite many different events being organised at that time, was still not able to effectively tackle major historical changes occurring in the world.

\section{The Emergence of the Non-Aligned Group and the 1961 Belgrade Conference}

The downfall of European colonial empires and the parallel rise of the Cold War bipolar world order served as a general background against which sweeping global changes had been introduced, ultimately serving as an impetus for the emergence of a distinctive group of countries actively pursuing non-bloc policies. The sounding majority of these uncommitted nations were post-colonial and underdeveloped ones, Yugoslavia being a notable exception as a bloc renegade and a modestly developed nation, primarily seeking preservation of their political and economic independence from any bloc encroachments, together with an intention of elevating their respective international positions, while also strongly advocating a more just and equitable world order that would eventually prove to be more in line with their basic needs and demands. The egalitarian character of the UN served as useful surroundings for launching any collective actions of these nations while providing them with a stage where they could, on an equal footing, conduct dialogue with the great powers on the issues of preservation of peace, lessening of international tensions, and pursuance of economic modernisation (Tadić, 1976, pp. 50-70). Historically speaking, nonalignment was all in one - a political doctrine, a practical foreign policy orientation, and an international movement, one fully tailored to suit the interests of small and lesser powers in world affairs, providing them with a sense of purpose, certainty, and predictability in their international dealings, thus eventually becoming an instrument for initiating collective actions that any of these nations could not successfully pursue individually on the world 
stage. Furthermore, non-alignment was primarily driven by strong opposition to any permanent identification or affiliation with any of the blocs or great powers, as well as by a clear necessity to put up continuous resistance to any external ideological, political or economic subjugation while actively promoting peace, equality, and development in international relations (Petković, 1974, pp. 18-23). Non-alignment was rather a pragmatic, morally neutral concept devoid of any ideological rigidity or dogmatic interpretation, regardless of its strong anti-imperialist and anti-colonial sentiments, mostly stemming from the general perception of insecurity and the overall burden of backwardness characteristic for many non-bloc countries, thus putting preservation of hardly-won independence and maintenance of freedom of action as its paramount goals (Mates, 1970, pp. 78-80). Ideas of anti-colonialism and anti-imperialism, often embodied in their pan-Asian or pan-African forms, stood at the very foundation of the strategic choice newly liberated countries had made for non-alignment, observing such a foreign policy course as the justification of their intensive aspirations to remain independent and persevere in world affairs. These individual strivings had acquired their collectivist impulses very early on, thus creating institutional precedents for the initial emergence of the nonaligned group and eventually also the NAM. One of them was the Asian Relations Conference convened in soon-to-be independent India in MarchApril 1947, while also meeting again within this specific format in January 1949 over the issue of the Indonesian independence struggle, where ideas about regional and inter-regional solidarity, as well as non-bloc adherence were already looming large (Jansen, 1966, pp. 51-74, 83-101). Despite being a failed format, this initiative served as a springboard for setting up an ArabAsian, later on, an Afro-Asian group in the UN, to which Yugoslavia also informally acceded, which acted as a predecessor to the future NAM voting bloc in the international organisation. This was primarily a collective response staged by small and recently liberated countries against the increasing pressure exercised by the great powers continuously seeking alignment with their respective interests, while also this group was offering third-party mediation services to the increasingly hostile blocs, especially during the Korean War (Kimche, 1973, pp. 35-39).

Initially, Afro-Asia was spearheading initiatives for gathering at least some non-aligned countries in one place, although this format often also encompassed countries from both continents which were already nurturing strong political and military ties to the two blocs, thus eventually pushing the non-aligned and Afro-Asian discourses along two different historical tracks. Following stabilisation of the security situation on the continent and 
the parallel détente in inter-bloc relations, during their respective meetings in Colombo and Bogor in 1954-55, prime ministers of five Asian nations (India, Indonesia, Burma, Ceylon, and Pakistan) decided to convene the first Asian-African Conference in the Indonesian town of Bandung in April 1955 (Ewing, 2019, pp. 1-19). This was the first groundbreaking summit where leaders of 29 nations from the two continents discussed major international issues and they offered corresponding solutions, a truly defining moment in the history of the Third World when Afro-Asia was largely speaking in one voice. The famous "Ten Principles" adopted in Bandung had left a lasting imprint on Third World politics and non-alignment in general by actively promoting racial and national equality, human rights, respect for sovereignty and territorial integrity, non-interference, wider cooperation, etc. In fact, the summitry format and strong anti-colonial drive had also become something characteristic for the non-aligned discourse afterwards (Dinkel, 2018, pp. 42-83). However, the indiscriminate presence of both bloc and non-bloc countries at this event, poorly defined geographical framework, regional isolationism, playing up of differences between the Afro-Asian majority and "white" minority in world affairs, all contributed to the limited effect the Bandung discourse produced internationally, pushing many authentic non-aligned countries, both on these two continents and beyond, to seek for an alternative format outside these artificially imposed regional and ideological constraints (Čavoški, 2009, pp. 79-80). In fact, Yugoslavia, as a European country, was highly interested in charting a separate collective non-aligned path, different from the Bandung one, which would raise high the non-bloc criteria for participation, as well as stress security and developmental issues, irrespective of the regional adherence of certain nations. In this effort, Yugoslav leader Josip Broz Tito was actively joined by his Indian and Egyptian counterparts, Jawaharlal Nehru and Gamal Abdel Nasser, as it was already demonstrated during the first tripartite meeting they held at the Brioni Isles in July 1956, sometimes nicknamed "Third World's Yalta". The three leaders would be charting ways to strengthen cooperation between key non-aligned countries, with Tito and Nasser opting more for a new non-aligned conference and Nehru being largely reluctant to back them up in this respect (Prashad, 2007, pp. 97-100). By the end of the 1950s, relations between the superpowers were at their lowest ebb in years, creating new frictions and additional confrontation in a number of places, like Berlin, Congo, Cuba, Laos, Algeria, etc. As a means of mitigating the burgeoning superpower conflict, five leading nonaligned countries - Yugoslavia, India, Egypt, Indonesia, and Ghana decided to launch a collective initiative at the $15^{\text {th }}$ UN General Assembly session in 
September 1960, aspiring to set off a new round of top-level dialogue between Moscow and Washington with an intention of further lessening already escalating tensions. Despite everything, this seemed like quite an auspicious moment since Cyprus and 16 West and Central African nations had recently gained their independence, thus joining the flock of the nonaligned. With Nehru still being reserved over the feasibility of any collective actions, Tito and Nasser, nonetheless, backed by Indonesian and Ghanaian leaders Ahmed Sukarno and Kwame Nkrumah, headed this diplomatic effort to which the Indian prime minister had to eventually subscribe. Even though the non-aligned resolution, the so-called the "Initiative of the Five", did not ultimately receive enough votes since it was largely subverted by Western diplomatic manoeuvres, it still stood as a clear signal that the role of the non-aligned countries was on the rise and their opinion was being increasingly taken into consideration by other relevant international factors (Bogetić, 2006, pp. 343-348). Regardless of this temporary setback, Tito decided to use his subsequent trip to a number of West and North African countries in early 1961 to feel the pulse of the non-aligned world and garner enough support for convening a new non-aligned conference. This entire initiative fell on right ears, with a number of influential Arab and African leaders, primarily Nasser and Nkrumah, standing firmly behind Tito's idea that the time was ripe enough for the non-aligned nations to hold their first summit, one where they could openly and actively address all pressing world issues. Sukarno, although engaged in his own attempts to have a second Bandung conference first, nonetheless, soon decided to opt for a nonaligned meeting, thus expressing his full backing for the Yugoslav-Egyptian initiative (Bogetić, 2006, pp. 349-362). However, Nehru still held on to his old reservations, considering that the time for a new summit was premature, while any such gatherings, in his mind, could only bring to the surface old divisions existing between many potential participants, thus eventually not rendering any desirable effect on the superpowers. Therefore, Tito's and Nasser's primary task was talking Nehru into finally attending the future summit while also soliciting his constructive contribution to its ultimate success. (Čavoški, 2015, pp. 60-66) When the Preparatory Meeting finally met in Cairo in June, the preliminary list of participants was put together, while the fundamental criteria of non-alignment were effectively laid down, thus clearly establishing a strict benchmark for any future membership, one which would not undergo any significant changes throughout the Cold War period (Jackson, 1983, pp. 43-44). Since the non-aligned were entering the centre stage of world politics, it was natural that the great powers would be quite eager to either influence the final outcome of the forthcoming summit 
or at least swaying some of the individual participants in their favour as a means of forestalling any excessive criticism of their respective positions. This was largely the case with the US and the USSR, with the Kennedy administration aspiring to have as many Western-leaning participants in Belgrade as possible while also exercising an influence on some Latin American nations from staying out of this event altogether, namely Brazil. On the other hand, Moscow was primarily interested in the future conference shoring up its position on Berlin, with the unexpected resumption of nuclear tests on the very day of the conference opening serving as Khrushchev's unhidden attempt at stealing Tito's international limelight (Bogetić, 2006, pp. 363-367). As for China, it was primarily interested in holding the second Afro-Asian conference, and it was using Indonesia as its back-channel ally since Beijing could not participate in any non-aligned format as still being formally aligned to Moscow, therefore the bulk of China's criticism was directed against Yugoslavia and its, in their mind, revisionist policies (Čavoški, 2021, pp. 88-90). The Belgrade Conference, as the very first non-aligned summit in history, took place in September 1961, with 25 participants and three observers from four different continents being officially present in the Yugoslav capital. This was a solemn event where, in Tito's words, the "consciousness of mankind" had gathered aspiring to transform themselves from objects into subjects of international affairs, sounding out their own respective position vis-à-vis major world issues that often undermined their own stability and future of the world at large (Government of Yugoslavia, 1964, pp. 17-22). Unlike the conference in Bandung, despite a certain amount of anti-colonial rhetoric still being present, with Sukarno leading the way in this respect, the issues pertaining to the East-West conflict and economic development had gradually gained the upper hand during the general debate, with many non-aligned countries seeking ways to lessen international tensions, while also being inclined to add more economic substance to the discourse on the future of newly liberated countries. Tito was particularly insisting on putting emphasis on this economic dimension of non-alignment, together with securing safer international surroundings, considering them the central issues for the future existence of the non-aligned world. In addition, he also saw this conference as the initial step in stimulating a more permanent and better organised collective action of all non-bloc factors in the world though still short of forming anything resembling an international organisation (Čavoški, 2014, pp. 197-200; Bogetić, 2006, pp. 368-376). In the conference's final documents, issues of peace and development were marked as the paramount responsibility of the entire world, not just the two blocs, and 
they were closely mirrored by the proclaimed goals of eradication of imperialism, colonialism, racism, oppression, instability, and inequality, while promotion of wider international cooperation, further adjustments between the bloc and non-bloc actors, as well as peaceful co-existence going beyond just the two dominant socio-economic systems were also put on the same footing. However, the most immediate effect of the Belgrade Conference was the initiation of the dialogue between the blocs and the nonaligned countries over the crucial issues of disarmament and economic development, particularly when the UN 18 Nations Disarmament Committee was set up in 1962 (with 8 neutral and non-aligned members), soon to be followed by the establishment of the UN Commission on Trade and Development (UNCTAD) in 1964, a platform where the developed and developing countries would equally conduct discussions regarding the potential overhaul of the entire international economic system (Lüthi, 2020, pp. 295-297; Dinkel, 2018, 110-111). As pointed out before, the Belgrade Conference was not the true birthplace of the NAM since the movement was officially established later on, but this was the starting point of a new tide in global history where new alternatives to great power politics, this one primarily being a non-bloc and intercontinental one, had started to forcefully emerge on the world stage, carrying forward the collective voice of this group of nations with respect to some of the central international issues, in parallel also shaping their political consciousness that any joint action might improve their overall position inside the existing international system, with a long-term aim of gradually changing the rules of the current global game. Furthermore, the basic topics of the non-aligned discourse, marking the next 30 years of its evolution, had also been carefully defined in Belgrade, thus making this event the true watershed and a point of origin in the history of global non-alignment, the non-aligned group, and the subsequent NAM.

\section{Confrontation and Crisis}

The period until the end of the 1960s represented a specific time for the non-aligned group when only one summit was held, the 1964 Cairo Conference, an ad hoc gathering similar to the one in Belgrade, and there were no other corresponding events until 1970, with only one ministerial conference taking place the year before. This was also a time when a number of core non-aligned leaders had disappeared from the historical scene, some of them passing away due to a shock caused by national defeat (Nehru and Nasser after the wars with China and Israel), while others were overthrown 
in a string of military coups, some of them even being sponsored by outside forces (U Nu, Sukarno, Nkrumah, Algerian leader Ben Bella, Malian leader Keita), thus fundamentally transforming the global landscape of nonalignment (Lüthi, 2020, 298-299). These sweeping global changes were also taking place in the aftermath of the Cuban Missile Crisis, when the two superpowers were increasingly opting for the spirit of accommodation in bilateral relations, primarily in Europe, while still actively pursuing their respective interests in the Third World, thus increasing their military involvement into that part of the world, like the US intervention in Vietnam, while carefully avoiding any direct confrontation. In this respect, external pressure on different non-aligned countries was on the rise, thus contributing to their increasing internal radicalisation. Besides, further escalation of the Sino-Soviet ideological and political split was also contributing to the rising tensions in Asia and Africa (Leffler, 2007, pp. 182233). In parallel, a profound political and ideological rift was also emerging among the non-aligned, between the "moderate" and "radical" members of the group, with the first ones (represented by India, Yugoslavia, and Egypt) pursuing moderation, pragmatism, realism, and balance in their dealings with the great powers, also considering issues like peace, security, and economic development as the paramount ones, while the others (represented by Indonesia, Ghana, Guinea, and Mali, also closely backed by China) advocated a relentless crusade against imperialism, colonialism, and oppression represented in the face of Western powers, thus gradually eroding the non-bloc character of non-alignment in favour of militant escapades directed at convening second Bandung in the place of another non-aligned conference. (Čavoški, 2021, pp. 92-94; Lüthi, 2020, pp. 298-299) In time, this period would mark the final conceptual divorce between the distinct regionalist "Afro-Asianist" path initiated in Bandung and the specific non-aligned independent course shaped and galvanised in Belgrade.

Before and especially after India's defeat in the border war with China in late 1962, Indonesia, strongly backed by China, had started actively pushing for convening another Afro-Asian conference that would, since it would raise high the banner of dedicated struggle against imperialism and colonialism, make the competing non-aligned conference format, one marked by less militant spirit, largely redundant and ultimately obsolete. In this respect, both Jakarta and Beijing were intensively trying to gain wider consent from different Asian and African nations, dispatching numerous high-profile delegations, like Premier Zhou Enlai's major Africa tour in 196364 that would lobby for a new regional gathering during these official visits (Zhou, 2019, pp. 145-149). This kind of activity had triggered great concerns 
in India and Yugoslavia. Both of them then engaged in a conflict with China since Beijing and its allies would obviously dominate any new regional format, while Yugoslavia, as a European country, would be completely left out from any conference encompassing only these two continents. Therefore, these two core non-aligned nations, also enjoying overt Egyptian support, had become ardent proponents of the new Belgrade-type conference considering it the only format authentically representing the interests of nonbloc nations (Čavoški, 2021, pp. 95-98). This race for convening either of these two conferences first would almost split the non-aligned world in half, causing great harm to the general cause, also casting a shadow of a doubt whether non-alignment with its less militant and more pragmatic approach was still the adequate means of constructing a new role for the post-colonial nations under existing international conditions. Strangely enough, both the US and the USSR stood in favour of the new non-aligned conference since none of the superpowers was quite keen on seeing Beijing taking control over the Third World. In order to outmanoeuvre its competitor, leaders in Yugoslavia, India, and Egypt had found a way to skilfully adopt some of the "Afro-Asianist" discourse regarding anti-imperialism and anti-colonialism and carefully merging it with non-alignment demands for strengthening peace, increasing international stability, and promoting economic modernisation. This new diplomatic tactic was also accompanied by demands for expanded participation of as many non-bloc countries as possible, from four different continents, thus largely offsetting any potential "radical" regionalist takeover of the non-aligned gathering (Jansen, 1966, pp. 363-383). The Cairo Conference was convened in October 1964, with 47 full participants and 10 observers attending this event. Right from the start, the above-mentioned conceptual conflict had come to the forefront, with Tito and Sukarno embodying these two increasingly conflicting approaches, thus triggering a heated debate between them on the role of peaceful co-existence in international affairs and whether it was possible to maintain constructive relations with the great powers, while also striving for the preservation of individual interests and gradually pushing forward the specific non-aligned agenda. Sukarno was convinced that the global rules were fundamentally rigged and newly liberated nations had to struggle with arms for their rightful place in the Cold War world order. For Tito, this was indeed a dangerous line of thinking since it clearly implied imposing a new racial and class division on the world which would substitute the existing ideological blocs - the poor against the rich, coloured against the white or similar. In the end, with certain adjustments made as a concession to African countries with respect to the struggle against imperialism and colonialism since for them 
that was a more real threat than a nuclear war, it was basically Tito's line that had succeeded in gaining the upper hand at this summit, thus creating a more or less general consensus on all major topics by creating a tentative linkage between the two concepts. Nevertheless, both Yugoslavia and Indonesia had also become aware that not everything they were advocating was acceptable to all participants. Therefore, compromises were painfully necessary, while the non-aligned group still remained a loose and nonpermanent form of mutual cooperation (Bogetić, 2019, pp. 115-128). The evident success of the Cairo Conference, regardless of many of its limitations, together with the continuous postponement of the Afro-Asian conference, which ultimately never took place, clearly indicated that the non-aligned discourse, with its specific set of ideas and values, had remained the only viable framework for joint political action of all forces standing outside the blocs. Nevertheless, this intensive struggle between the two conference models had largely exhausted the vitality of the non-aligned group, shifted its focus, and dimmed its prospects, thus compelling many nations to reduce their enthusiasm for launching any new global initiatives. The obvious failure of the non-aligned Vietnam War mediation stood as a stark reminder of the lack of resourcefulness these nations suffered from in the years following the Cairo Summit (Rakove, 2013, pp. 225-231). For almost five years after that event, the non-aligned group underwent a profound organisational and ideological crisis which resulted in no new non-aligned gatherings being summoned, with many new initiatives for collective action experiencing lack in wider response or readiness to engage beyond only verbal messages. The internal turmoil in many non-aligned countries, one that swept away from the historical scene many prominent leaders, wedded together to this total diplomatic paralysis of the entire group, seemed to indicate that nonalignment was experiencing increasing irrelevance (Westad, 2005, pp. 107108; Lüthi, 2020, 300-302). While the superpowers were slowly constructing détente that would start dominating global affairs during the 1970s, the Third World was entering a period of rising instability and expanded bloc interventionism. Besides the escalation of the Vietnam War that locked the attention of both Washington and Moscow to Asia, Egypt's defeat in the June 1967 war with Israel, one also closely associated with the superpower policies in the region, had produced a destructive effect on the cohesion and future of the non-aligned group, since after those tragic events Nasser was forced to seek protection under the Soviet tutelage, expressing less and less interest in spearheading any new non-aligned initiatives or organising any new major events of that sort. Yugoslavia and India were quite disturbed with such negative developments that had fractured the very core of global non- 
alignment, while their individual attempts at mediating this new conflict in the Middle East also proved to be without any durable effect, further contributing to Nasser's growing isolation from other non-aligned countries (Bogetić, Životić, 2010, 131-209). Under the influence of the deteriorating situation in the Third World, Yugoslavia decided to launch its own initiative for convening another non-aligned summit in 1968, one that would address all key international issues, especially the ones pertaining to inequality and problems of economic development, thus also introducing new vigour into the group, while also serving as a potential incentive to different disenchanted bloc allies around the world into eventually defecting into the non-aligned flock. This entire idea was greeted with significant enthusiasm in countries like India, Ethiopia, Zambia and others, but there was still not enough willingness present to transform this kind of verbal eagerness into any concrete action (DAMSPS, PA, 1968, f-145, 418435). Therefore, Yugoslavia, India, and Ethiopia decided to assume leadership and actively court a few dozen non-aligned countries into holding at least a consultative meeting in 1969 since that would signal to the rest of the world that the nonaligned alternative was still very much alive and active, even if a new summit was not at hand. Without such an event taking place, irrespective of its true scope or relevance, global non-alignment would have totally lost its credibility and continuity, and very soon it would have ceased to exist (TNA, FCO 28/868). This first major event since the Cairo Conference was the Belgrade Consultative Meeting in July 1969, where representatives of 44 nonaligned countries and 7 observers, actively strived to define a new platform for collective action, one primarily dealing with stabilisation and democratisation of international relations, creation of a more equitable and just world economic system, together with the stressed centrality of the UN as the crucial forum where different non-aligned initiatives could be successfully presented and ultimately implemented by becoming binding for all member states, including the great powers (Institute, 1970, pp. 29-174). Although this was a meeting of a limited impact, without a new summit being anywhere near on the horizon, nonetheless, this new gathering reaffirmed the vitality and continuity of non-alignment, raising its international profile again, thus also emphasising, even more, the permanent character of this still informal group of nations. In fact, that was Yugoslavia's chief contribution in this respect, bringing non-alignment out of a protracted internal crisis that could have ultimately proved to be fatal, even before the NAM was officially established. Soon enough, it was decided to hold the next summit in the Zambian capital Lusaka in September 1970, announcing a 
major comeback for the non-aligned option in world affairs, now transforming itself into a fully-fledged international organisation.

\section{The Golden Years of the NAM}

During the 1970s, the world at large was undergoing fundamental political, economic, and social changes that had created an increasingly interconnected and interdependent world, not only at the level of superpower interactions, like the initiation of an inter-bloc détente, but also in the domain of relations between the developed and developing nations as part of the general trend of creating more stable and prosperous societies. In many ways, unlike in the previous period, the spirit of cooperation, irrespective of its scope and goals, while encompassing all members of the international community, was also permeating international relations in many areas, leaving the ominous shadow of nuclear confrontation in the past, at least in a more general sense, since regional conflicts affecting some non-aligned countries were still widely present (Garthoff, 1994, pp. 27-73, 227-294, 325-403). While the superpowers were reaching accommodation at the strategic level, gradually reducing tensions in the world, the non-aligned were also undergoing a transformation from a loose group of nations perceiving non-alignment only as a verbal conceptualisation of a practical foreign policy course into a globally recognised and institutionalised movement that perceived non-alignment as a sovereign international doctrine following a set of well-defined ideas and principles. Besides, during this period, the NAM was also rearranging its global agenda along these new lines, going well beyond the issues dominating the discourse of the 1950s and 1960s, such as bipolar confrontation and decolonisation, thus shifting its focus more to economic and developmental problems, preaching of the restructuring of the existing world economic system as to serve more the needs of the underrepresented majority, while also advocating tighter political and economic integration of the Global South (Lüthi, 2020, pp. 429436, 446-451). This rising trend among the non-aligned primarily directed at completing the movement's institutionalisation, promoting continuity, and emphasising economic orientation as its new strategic goal was already evident during the Preparatory Meeting for the Lusaka Summit held in Dares-Salaam in April 1970, when Tanzanian leader Julius Nyerere publicly proclaimed that socio-economic development should dominate the nonaligned agenda from then afterwards, but one primarily relying upon collective self-reliance represented in the radical expansion and diversification of South-South relations, namely through boosting economic 
and technical cooperation and exchanges between the developing and nonaligned countries themselves, while also carefully introducing collective protective economic mechanisms from any future predatory encroachments of the industrialised world (Nyerere, 1970). Such new developments would become even more evident during the fourth summit in Lusaka in September 1970, when 54 attendees and 10 observers largely debated issues pertaining to the non-aligned countries themselves, like independence, development, and self-reliance, as well as the future of the movement, while major global issues, like bloc confrontation, arms race, and world peace, would continue to loom large in the background but without ever taking the front seat in any deliberations. The general economic orientation of the movement was strongly reiterated again, while the first permanent institutions of the NAM were then established, like the Standing Committee, more a technical than a political body representing the movement on the world stage, which served as a catalyst for the perpetuation of the continuity of action now personified in regular summits being held every three years, with ministerial conferences also being convened in the meantime (NAI, MEA, WII/128(2)/70). Essentially, only after Lusaka, we can mention an organised international institution and not any time before, while the NAM was rapidly transforming itself into an agency of the North-South and not only the East-West conflict as it used to be the case, with principles like collective self-reliance, agreed the programme of action, and raising high the overall moral authority acting as propellants of any future activities, particularly inside the UN. Therefore, further institutionalisation, as well as strengthening of any collective mechanisms for launching corresponding actions, had become the guiding thought of any new undertakings assumed by the NAM in the following years (DAMSPS, PA, 1971, f-190, 44854). In many ways, a significant shift in leadership was also occurring during this period, with Yugoslavia and India still preserving their somewhat special position inside the NAM, although often being compelled to share their leadership responsibilities with others, while Egypt was participating at a reduced capacity due to its active involvement in the Middle Eastern conflict, similar to countries like Indonesia and Ghana, while some other African nations, primarily Algeria, Zambia, and Tanzania, as well as some Asian and Latin American ones, like Sri Lanka or Cuba, were also gaining more weight, influence, and respect inside the movement (CREST, CIARDP85T00875R001500020044-2). While directing the bulk of its efforts into pursuing this new economic agenda of restructuring the world system, the NAM was also dedicated to promoting global détente as a more universal endeavour, one that would, as they perceived it, went well beyond the two 
blocs and it would produce a lasting impact on all other nations in the world, thus correspondingly strengthening international security and boosting economic prosperity, while gradually breaking up the existing global status quo that very much petrified the current level of inequality between the developed and developing nations (DAMSPS, PA, 1972, f-142, 424377). This line of thinking was very much present during the Ministerial Meeting in the Guyanese capital Georgetown in August 1972, a first major event after the Lusaka Conference, one not only dedicated to the preparations for the next summit in Algiers. In fact, the NAM was then seriously deliberating international situation, searching for ways in which it could successfully expand the superpower détente into other regions of the world, while in parallel also strengthening the role of the UN where the great powers could be still held accountable for any of their actions and where the collective action capacity of the NAM could produce the most tangible effect on both blocs. In addition, at this gathering a comprehensive programme for a more intensive economic cooperation among the non-aligned and developing countries was charted, one that would produce a clear set of guidelines and a list of specific measures, more concrete than the ones adopted at Lusaka, that would directly assist the NAM in its struggle for the top-to-bottom overhaul of the international economic system (Bogetić, 2019, pp. 219-230). Even during the preparations for the Algiers Summit, it had become evident to different observers and participants that this event would become another watershed moment in NAM's evolution, a true "conference of action", largely driven by an overarching idea of reshaping the NAM into an effective tool of the non-bloc and developing countries in their continuous efforts to vociferously oppose hegemonic activities of both blocs. This was a specific moment when new, more adequate and more efficient means of staging any collective undertakings would be implemented to guarantee a more viable and enduring political and especially economic co-existence between the developed and developing worlds. The Algerian side was particularly interested in utilising this event as a stage where the account for incessant Third World pauperisation and suffocating backwardness would be unanimously presented to the Global North as a new incentive for re-launching the global dialogue which had remained stalled at different UNCTAD sessions (DAMSPS, PA, 1973, f-132, 432576). When the Algiers Conference finally took place in September 1973, already 75 nations attended as full members, with many others being present as observers and guests, thus making this event the largest congregation of nations after the UNGA. Essentially, the process of NAM's institutionalisation, initiated at Lusaka, was finally completed during this summit, when the Coordinating Bureau 
(CB) was founded as a kind of its executive body, while the political and economic goals of the movement were better ascertained or even redefined, thus stimulating additional concentration of all non-aligned resources through establishing new mechanisms of mutual cooperation and coordination. In many ways, one of NAM's major assets, its undeniable moral strength, was then transformed into a more concrete one, embodied not only in the overwhelming numbers in the UN but also present in the immediate control many members exercised over key raw materials, like oil or similar (AJ, 837, KPR, I-4-a/15; Bogetić, 2019, pp. 243-264). These strivings were encapsulated in the new concept launched at this event - the New International Economic Order (NIEO), a call for the establishment of a more balanced, inclusive, and mutually beneficial world order, one closely linking security and economic issues, diminishing foreign interference and inequality, recognising sovereign rights of all nations, while also being more attuned to the needs of its most deprived members, who were themselves continuously subjected to unfair trading practises by the developed world (Prashad, 2007, pp. 67-70; Dinkel, 2018, pp. 202-204). The NIEO would represent the most serious structural challenge posed to the Western economic hegemony in the $20^{\text {th }}$ century, one that would, despite its eventual failure, rock the very foundations of the post-war economic and financial system and try to shift the balance between the Global North and Global South more in favour of the latter one, thus promoting a more profound and diversified level of socio-economic interdependence and tighter international integration between these two major parts of the world (Garavini, 2012, pp. 174-183). One event which served as a direct trigger for restarting the global dialogue between the developed and developing worlds was the OPEC oil embargo introduced as a response to the next Arab-Israeli war in October 1973, subsequently causing the worldwide economic crisis, recession, inflation, and significant drop in industrial production. This precarious turn of events only demonstrated that the developing world had also gained its muscles, particularly in the sphere where it still maintained leverage - raw materials, thus gradually starting to dictate some of its own terms to the Global North (Venn, 2002, pp. 7-21, 154-163). As a means of taking over the global initiative while the West was still recuperating from this shock, the NAM decided to call for the $6^{\text {th }}$ UNGA Special Session in April 1974 where the economic and developmental issues, especially raw materials and inequalities, would be discussed in-depth, thus further promoting Third World economic solidarity vis-à-vis the developed world, while the struggle for a new face of the world economic system would be only intensified, especially by setting up fresh international 
financial institutions. The NIEO was globally introduced at this event through two concurrent UNGA resolutions (TNA, FCO59/1231). Naturally, such demands for an obvious redistribution of the global wealth were bound to stir trouble among the industrialised powers, forcing the US and its allies to close in the ranks and try to adamantly oppose any such initiatives, perhaps not on all accounts but the majority of them definitely, while also trying to drive a wedge between the rich and poor non-aligned countries. Since the NAM was acting more and more as a disciplined voting bloc in the UN, this caused even more frustration in Washington since it was contributing to the growing US isolation in this international institution (Garavini, 2012, pp. 215-224). This newly found strength in numbers was already evident during the $29^{\text {th }}$ UNGA session when, through the overwhelming majority of NAM votes, the PLO was accorded an observer status, while South Africa, due to its apartheid policies, was expelled from this body, regardless of harsh Western criticism of both these moves (DAMSPS, PA, 1974, f-174, 461984). Even though the Western powers were gradually consolidating their former grip on the world economy, it seemed as if the NAM was still on the offensive, almost at the tipping point of radically changing the existing world order. During the Ministerial Conference in the Peruvian capital Lima in August 1975, the movement had again proclaimed its strong commitment to the full implementation of the NIEO, concurrently extending its hand of cooperation and conciliation to the developed world. However, a majority of the NAM members also denounced any outside accusations that the nationalisation of natural resources in the Third World stood at the origins of the current economic crisis, thus emphasising that the dominant position of the developed world, its obvious lack of enthusiasm or willingness for extending additional assistance, easing the debt burden or sharing the responsibilities for running the world economy were more to be blamed for such an outcome than any other reasons. This conference also radically redefined and expanded areas of South-South cooperation while also establishing the new NAM bodies that would deal with issues such as raw materials or mutual financial assistance (AJ, 837, KPR, I-4-a/20; Bogetić, 2019, pp. 329-336). The NAM's clear position and different active measures also significantly influenced the Western position during the $7^{\text {th }}$ UNGA Special Session in September 1975, when the developed countries proved to be more prone to offering some tangible concessions on a number of issues but still without tackling the more fundamental ones, thus essentially waiting for the non-aligned to lose some of their initial momentum and start to doubt their own strength (DAMSPS, PA, 1975, f-198, 443405). On the other hand, besides these 
attempts at implementing the NIEO, at that time, the NAM also launched another significant global initiative that aimed at restructuring the great power monopoly on information collection and broadcasting, thus creating a new pool of non-aligned news agencies that would supplement the work of their major counterparts in the North (AP, AFP, UPI, Reuters, DPA, TASS), which eventually heralded the so-called "New International Information Order" (NIIO) actively promoted by countries like Yugoslavia and India (Dinkel, 2018, pp. 196-201). Due to all these complex international developments, as well as the concurrent completion of the nationalliberation struggle in Indochina and the Portuguese colonies in Africa, the Colombo Conference in August 1976, together with its 86 full members attending, with more than two dozen observers and guests also being present, seemed like a prime moment for the NAM in global affairs, while moderation and spirit of cooperation largely permeated the discussion. This was a summit where the direct link between the political and economic dimensions of international relations was stressed even more, with the NIEO standing at the forefront of a struggle for the general overhaul of the entire world order in which the non-great power alternative would legitimately exist alongside the two blocs and other great powers. Nevertheless, all participants agreed that more needed to be done in order for such a radical idea to eventually become a reality, especially in the sphere of reshaping the global trading rules and the reorganisation of global production. In this respect, the new movement's bodies dealing with different economic issues were set up, while the $\mathrm{CB}$ membership was also significantly expanded to make the NAM more adept at rapid responses to sudden changes in the international situation. On the other hand, this summit was also the very first time when the results of the superpower détente were openly brought into question, considering them as being put only into service of immediate interests of the superpowers and not the wider world (AJ, 837, KPR, I-4a/26; Bogetić, 2019, pp. 359-378).

The second half of the 1970s was clearly marked by the deteriorating situation in the superpower dealings, which eventually resulted in the total dissolution of détente by the end of that decade and the initiation of a new intensive round of bloc confrontation. Not only that superpower interventionism, direct or proxy one, was on the rise in places like Indochina, Angola, Ethiopia, Lebanon, South Yemen, Nicaragua, and Afghanistan, but conflicts between the non-aligned countries themselves, especially territorial ones, were also escalating in many different regions, particularly in Africa, thus also affecting the NAM's unity and cohesion, while also adding another nail into the coffin of global détente. (Garthoff, 1994, pp. 623-685, 732-824, 
829-912) As for the movement itself, while it was still rapidly expanding its membership and convening a growing number of events, it was also undergoing increasing internal destabilisation as part of these different bilateral conflicts, thus signalling NAM's decreasing effectiveness on the world stage and its incapacity to timely react to these new developments. This negative trend was also accompanied by rising factionalism between the "moderate" and "radical" members, with the first group striving to preserve the movement's original non-bloc orientation, while the latter ones, both leftist and rightist ones, were opting for closer alignment of the NAM with one of the two blocs. Since the US was experiencing a strategic retreat at that time, while the Soviets were gaining ground in different parts of the world, the leftist faction (Cuba, Vietnam, Laos, Ethiopia, Angola, Mozambique, South Yemen and others) was correspondingly gaining strength while trying to refashion the NAM into becoming a "natural ally" of the Soviet bloc (Singham, Hume, 1986, pp. 167-171). These attempts at taking control over the movement by a small group of radicalised nations, openly leaning towards one bloc, would trigger a serious conflict between the two factions for leadership, with Yugoslavia and Cuba standing at the helm of each side, especially since the next summit was scheduled to be held in Havana (NARA, RG 59, CFPF, 1973-1979, ET, 1978USUNN01534). This profound internal crisis of the NAM, manifesting itself in the shape of decreasing levels of mutual solidarity, spurring many dilemmas about the basic goals, fundamental character, and general practices of the movement, often resulted in different countries opting more for passivity and maintaining a low profile, thus in return creating a significant breach a group of proactive countries could then try to utilise and to impose its own agenda on others, while concurrently assuming more direct control over the entire organisation. At the same time, this sombre scenario could have also triggered a harsh Western response in which the NAM members close to the US could strive for splitting the movement in order to save it from Soviet domination, with Cuba acting even more radically in response to that, thus spelling the effective end of the movement (DAMSPS, PA, 1978, f-187, 427404). These were worrisome tendencies indeed, which largely preoccupied countries like Yugoslavia, India, Sri Lanka, Algeria, Egypt, Zambia, Tanzania, Indonesia and many others. The Ministerial Conference in Belgrade in July 1978, although expected to become a showdown between the Yugoslav and Cuban delegations, finally ended in a tentative compromise more along the Yugoslav lines, reaffirming again the basic principles of non-alignment, regardless of the fact that ideological polarisation was not fully removed from the non-aligned ranks. In fact, the 
majority of members had emphasised once again the non-bloc and independent character of the NAM, with less emphasis being put on the anti-imperialist struggle as the Cubans aspired (AJ, 837, KPR, I-4-a/30; Bogetić, 2019, pp. 443-456). Nevertheless, a new trial of strength between Yugoslavia and Cuba was scheduled for the Havana Summit, with Belgrade somewhat altering its overall diplomatic tactics by transforming the Yugoslav-Cuban bilateral confrontation into a wider conflict between the respective Cuban ideological agenda and the silent majority of the NAM over the movement's fundamental principles. On the other hand, Cuba also intended to present itself to the wider public as being far more constructive than before, but behind the scenes, it was also pedalling even harder in promoting the anti-imperialist and anti-colonial essence of the movement (DAMSPS, PA, 1979, f-184, 47123). This new round of confrontation especially manifested itself during the discussion over "Agenda Item 15", an attempt at improving the decision-making process inside the NAM and the $\mathrm{CB}$ by implementing more the spirit of democracy, openness, and solidarity, thus further limiting the role of Cuba's future chairmanship, while also expanding the executive role and membership of the $\mathrm{CB}$ over which Havana could not assume control after the summit (DAMSPS, PA, 1979, f-205, 423375). Despite growing concerns and a somewhat pessimistic atmosphere among many members, it was becoming increasingly evident that the summit agenda was shifting more in the direction of the "moderate" group. The Havana Conference in September 1979, with 92 full members and dozens of observers and guests being present, was the last major international event attended by Tito who, despite his advanced age and feeble health, decided to travel across the globe in order to ensure that the movement would survive him in the same pristine condition as it had been before, especially since both superpowers were overtly trying to influence the proceedings and outcome of this event. Tito then served as a rallying point for the entire "moderate" group, also succeeding in patching up some of the differences with Castro right on the eve of the summit (Petrović, 2010, 263-269). Nevertheless, in their respective speeches, both Castro and Tito were still pursuing their own lines of argument regarding the NAM's present and future, although without any zeal expressed to impose their own views on other participants, which was, despite everything, bound to stir certain controversies among other speakers. However, despite an unsuccessful attempt at materialising the "radical" onslaught, the sounding majority of participating leaders opted for Tito's ideas, openly backing his agenda, while also sidelining some other attempts at redirecting summit deliberations. Even when it came to the drafting of final documents, the 
Cubans were compelled to seek compromises with countries like Yugoslavia, India, Algeria and many others, thus bringing more balance into their content, both in a political and economic sense. In general, the majority of participants ultimately succeeded in reiterating the independent, non-bloc, and democratic character of the NAM, while successfully sidelining the Cuban thesis on the "natural alliance" and revolutionary character of the movement (NAI, MEA, HI/162/11/79; Bogetić, 2019, pp. 499-526). Nevertheless, this confrontation between the two factions in the movement had largely drained out its vitality and purposefulness at one of the most dangerous moments in recent history when the superpower conflict was raging again, even though the Cuban chairmanship assiduously tried to maintain a more reserved and balanced approach to the NAM affairs. Since Tito soon passed away, thus ending the "golden years" of nonalignment, many feared that Cuba would use that rare opportunity to try to impose its own views again, but that did not happen either. Neither Castro nor the movement had any strength to wage a new round of struggle over the issue which had already become an outmoded one. Cuba's open endorsement of the Soviet invasion of Afghanistan, a NAM member, primarily a result of Havana's significant dependence on Moscow, eventually did more to harm Cuban prospects inside the movement than any Tito's undertakings ever could. All in all, the movement was entering a period of a comprehensive crisis from which it would be very hard to extricate itself.

\section{Crisis and Decline}

The onset of the Second Cold War, as well as the growing conceptual rift between the different NAM members, had soon plunged the movement into further disarray, increasingly contributing to its decline in world affairs throughout the 1980s. While the international political and economic situation was on a downward spiral, with the calls for the NIEO remaining effectively dead in the face of an emerging neoliberal alternative of free markets, foreign investments, and private initiatives, many non-aligned countries had started to seek individual solutions to their own problems, especially with respect to bilateral conflicts, acting well outside the NAM's scope, thus signalling a serious loss of confidence in movement's ability to find adequate solutions. This complicated nexus of external and internal pressures largely contributed to NAM's subsequent unwillingness to take the lead, spurring growing pessimism among its many members, thus clearly indicating that the movement had lost much of its original orientation 
and penchant to act as an independent global mediator (Westad, 2005, pp. 334-338, 357-362; Prashad, 2007, pp. 245-259). Many influential members were already openly talking about "fragmentation", "dislocation" or "regression" of the movement, labelling the early 1980s as the most serious crisis the NAM was facing in the previous 20 years (DAMSPS, PA, 1980, $\mathrm{f}$ $217,416387)$. Therefore, since many concrete issues could still trigger new disagreements between different member states, renewed insistence on the global context could have served as a means in redefining and reinventing the long-term goals of the movement, gradually introducing more balance into its handling of global, regional, and local interests pursued by individual members, thus ultimately revitalizing non-alignment and the NAM and correspondingly strengthening the role of the "moderate" wing (DAMSPS, PA, 1980, f-178, 49458). This has been particularly true since the Cuban chairmanship, due to Havana's open support for the Soviet invasion of Afghanistan, was facing a growing deadlock and Cuba was no longer able to bridge this chasm in a constructive way that could preserve the movement's unity and purpose unscathed. For the majority of the NAM members, great power interventionism had become the greatest threat to the very existence of particular countries, with Cuba continuously pushing justified grievances under the carpet, thus preventing the NAM to fully exercise its mandate and reach a meaningful consensus. This only further contributed to NAM's growing paralysis (DAMSPS, PA, 1981, f-202, 41251). Even though it could not resolve many of the existing controversies, the Ministerial Conference in New Delhi in February 1981 still managed to push the NAM back from the brink of dissolution, somewhat minimising the damage, and levelling out some of the disagreements, while also reintroducing a certain level of accommodation into mutual dealings, at least with respect to specific issues (Jain, 2000, pp. 244-252). While the NAM was still trying to facilitate de-escalation between the superpowers, together with promoting a new agenda pertaining to the issues of security and development, the Iran-Iraq War, the bloodiest conflict between the two nonaligned countries during the 1980s, had become the greatest obstacle not only to the unhindered functioning of the movement but also to the successful organisation of the next summit which was originally planned to be held in Baghdad. Furthermore, countries like Yugoslavia, India, Sri Lanka, Algeria and many others clearly aimed at transforming the next summit into an event where four years of a protracted internal crisis would finally end, thus bringing the NAM back to its original track (DAMSPS, PA, 1982, f-159, 421223). It took a lot of diplomatic haggling throughout 1982 to induce Iraq to renounce its credentials as a host and transfer them to India, 
with Yugoslavia and Cuba leading the way in holding direct negotiations with the Iraqi leadership and offering corresponding incentives to save their faces and accept a compromise (DAMSPS, PA, 1982, f-160, 439929). In many ways, the strength of the "radicals" had clearly started to fade away, while India's future chairmanship seemed to offer a much-desired opportunity for the "moderates" to significantly reduce tensions between the conflicting factions, thus creating some breathing space for initiating the revitalisation of the movement. In fact, India opted for the middle-of-the-road tactics directed at creating a meaningful consensus that would keep any radical proposals out of the summit proceedings and final documents while holding steadfast with respect to some of the more fundamental issues. It seemed to different participants that the New Delhi Conference, held in March 1983, was the last chance for ending the protracted crisis and restoring some of the international prestige the NAM used to have. In her opening speech, Indira Gandhi was emphasising points on which the majority of participants could easily agree. She emphasised the basic values and strategic goals of the movement (peace, independence, security, development), while she dedicated most of her attention to the economic issues as still being the central ones for the future of the NAM and the developing world in general, thus bringing back the constructive discussion to the ideas previously promoted at the Colombo Summit. Many of the old political and economic messages of the previous summits were reiterated again in the final documents, with the stress being laid on the issue of interdependence, implying equal participation of big and small, rich and poor countries in running the world, while the Third World indebtedness was particularly singled out as the key factor leading to its excessive instability (DAMSPS, PA, 1983, f-153, 411263). India's subsequent chairmanship had managed to restore balance into NAM's ideas and practices, moderation had become the mainstream once again, and fundamental principles had been reaffirmed again, with the radicalisation drive initiated in the late 1970s effectively ending. This sudden shift in NAM's posture had succeeded in preserving the movement's unity and continuity, saving it from an almost imminent withering away although its previous dynamism had still remained diminished. Nevertheless, many of the pressing global challenges needed to be properly addressed by the movement to secure its future progress (Singham, Hume, 1986, pp. 330-335). On some occasions, India was often acting timidly, trying to avoid any new internal splits or adverse superpower reactions, but such an approach only led the NAM into further stagnation, justifying the sense of helplessness among many members. The NAM meetings were being regularly held, producing different documents, 
but no corresponding action ever came out of these gatherings. In many ways, the NAM had started to lag behind major world events, failing to formulate a strong and coordinated response with respect to different conflicting situations. The "radicals" from both sides were still launching attempts at turning the tables on others, although without achieving any tangible success, while the dominant "moderate" majority had lost the willpower to act regardless of any extreme opposition (Jain, 2000, pp. 262268; Dinkel, 2018, 238-242). Despite seminal changes taking place in the world with the initiation of the high-level dialogue between the superpowers after Gorbachev's ascendancy to power, the NAM was still mired in old ideas, not fully comprehending what was taking place around it, very much losing its old momentum, as well as its capability to innovate and adapt to the world of the future. Many members were just passively going along with the current, being aware that beyond the NAM there were no similar organisations representing their collective interests, while, on the other hand, they had also become painfully aware that the movement was no longer acting as the chief advocate or protector of their individual needs. This situation was more than evident during the Harare Conference in September 1986 when there were no new members joining the NAM, far fewer heads of state were present, while the superpowers were almost totally ignoring this event. Furthermore, for the very first time, it was not ascertained where the next summit would be held, leaving that decision to be made in the future (Rajan, 1990, pp. 85-104). Yugoslavia, although experiencing profound internal crisis by the end of that decade, still accepted to host the next summit in Belgrade in 1989, aspiring to find new ways in which the NAM would reinvent its global role beyond the Cold War world, integrate itself more successfully into an emerging world order, while also establishing a new social, economic, humanitarian, and ecological paradigm for the movement, one revolving around issues like sustainable development and further global integration in terms of markets, capital flows, and technology transfers. In fact, particular stress was laid by the Yugoslavs on environmental issues, ones equally affecting both the developed and developing worlds, thus finding a new common denominator for rebooting the North-South dialogue. By that time, the old rallying cry of the NIEO was laid to rest (Srivastava, 1995, pp. 125-131). Due to such new pragmatic guidelines, the NAM has managed to prolong its existence until nowadays, with nine more summits following the one in Belgrade, experiencing many ups and downs along the way, still striving to redefine its global presence in the post-Cold War world, one being clearly marked by both the unipolar moment of the US and growing multipolarity 
gradually supplanting it. Only the future will tell which path the NAM would take in the following years, one of a newly found dynamism or growing irrelevance, primarily taking into account the rapidly changing international situation, as well as the game-changing economic and political rise of different nations in Asia, Africa, and Latin America that would gradually start to dominate the international landscape.

\section{Conclusions}

As we have seen in this chapter, the NAM's international role during the Cold War decades should not be observed as either an epic narrative where the Third World was successfully struggling against the West, nor should it be treated as an outright failure without any corresponding achievements as it has been usually presented from the vantage point of the post-Cold War years. It is fair to say that the movement, during the decades at stake, had undergone many ups and downs, experiencing both successes and failures, often circulating between the East-West and North-South conflicts, stressing the political or socio-economic issues depending on the global situation, with different member states assuming the leadership role in accordance with the specific historical circumstances. Despite these evident fluctuations, the NAM was still one of the major multilateral political phenomena that had left a lasting imprint on world history after 1945, sideby-side with the superpower blocs. In fact, one of NAM's key achievements during that period was the successful completion of the process of decolonisation, together with the socio-economic agenda becoming the central topic of the non-bloc and developing worlds, especially with respect to issues like building a more democratic, just, and egalitarian world order that would eventually eradicate poverty, underdevelopment, and social insecurity. Until nowadays, these have remained the chief aspiration of the Global South. In essence, NAM's lessons from the Cold War period have not outlived their usefulness in today's world, with many developing nations rapidly losing confidence in any potential alignments with the great powers, while pursuing independent foreign policy and boosting SouthSouth cooperation has still remained their clear priority as it used to be the case in the past, together with the UN preserving its role as the centre stage for any new initiatives being launched by these countries. Furthermore, maintaining a viable multilateral alternative outside the UN framework might seem like a winning ticket for the NAM in finding its new role in the $21^{\text {st }}$ century. 


\section{References}

Archives of Yugoslavia (AJ), Cabinet of the President of the Republic (KPR)

Bogetić, Dragan. (2006). Nova strategija spoljne politike Jugoslavije 1956-1961. Beograd, ISI.

Bogetić, Dragan. (2019) Nesvrstanost kroz istoriju: od ideje do pokreta. Beograd, Zavod za udžbenike.

Bogetić, Dragan. Životić, Aleksandar. (2010). Jugoslavija i arapsko-izraelski rat 1967. Beograd, ISI.

Čavoški, Jovan. (2009). Jugoslavija i kinesko-indijski konflikt 1959-1962. Beograd, INIS.

Čavoški, Jovan. (2014). "Between Great Powers and Third World Neutralists: Yugoslavia and the Belgrade Conference of the Nonaligned Movement 1961" in: Nataša Mišković, Harald Fischer-Tine, Nada Boškovska (eds), The Non-Aligned Movement and the Cold War: DelhiBandung-Belgrade. London, Routledge.

Čavoški, Jovan. (2015). Distant Countries, Closest Allies: Josip Broz Tito, Jawaharlal Nehru and the Rise of Global Nonalignment. New Delhi, Nehru Memorial Museum and Library.

Čavoški, Jovan. (2021). "Shaping Afro-Asia and Non-Alignment: the SinoYugoslav Struggle for Leadership in the Third World during the 1950s and 1960s" in: Martin Previšić (ed.), Breaking Down Bipolarity: Yugoslavia's Foreign Relations during the Cold War. Berlin: De Gruyter Oldenbourg.

CIA Records Search Tool (CREST)

Dinkel, Jürgen. (2018). The Non-Aligned Movement: Genesis, Organization and Politics (1927-1992). Leiden, Brill.

Diplomatic Archives of the Foreign Ministry of the Republic of Serbia (DAMSPS), Political Archives (PA)

Ewing, Cindy. (2019). "The Colombo Powers: Crafting Diplomacy in the Third World and Launching Afro-Asia at Bandung". Cold War History 19.1, pp. 1-19

Garavini, Giuliano. (2012). After Empires: European Integration, Decolonization, and the Challenge from the Global South. Oxford, Oxford University Press.

Garthoff, Raymond L. (1994). Détente and Confrontation: American-Soviet Relations from Nixon to Reagan. Washington, DC, Brookings Institution. 
Government of Yugoslavia. (1964). Conference of Heads of State or Government of Non-Aligned Countries, Belgrade, September, 1-6, 1961. Belgrade, Jugoslavija.

Institute for International Politics and Economics. (1970). Consultative Meeting of Special Government Representatives of Non-Aligned Countries: Belgrade, July 8-12, 1969. Beograd, Međunarodna politika.

Jain, S.B. (2000). India's Foreign Policy and Non-Alignment. New Delhi, Anamika Publishers.

Jansen, G.H. (1966). Afro-Asia and Nonalignment. London, Faber and Faber.

Kimche, David. (1973). The Afro-Asian Movement: Ideology and Foreign Policy of the Third World. Jerusalem, Israel Universities Press.

Leffler, Melvyn P. (2007). For the Soul of Mankind: the United States, the Soviet Union, and the Cold War. New York, Hill and Wang.

Lüthi, Lorenz M. (2020). Cold Wars: Asia, Middle East, Europe. Cambridge, Cambridge University Press.

Mates, Leo. (1970). Nesurstanost: teorija i savremena praksa. Beograd, IMPP.

National Archives and Records Administration (NARA), Record Group (RG), Central Foreign Policy Files (CFPF), Electronic Telegrams (ET)

National Archives of India (NAI)

Nyerere, Julius. (1970). Non-Alignment in the 1970s: Opening Address by J.K. Nyerere. Dar-es-Salaam, Government Printer.

Petković, Ranko. (1974). Teorijski pojmovi nesvrstanosti. Beograd, Rad.

Petrović, Vladimir. (2010). Titova lična diplomatija: studije i dokumentarni prilozi. Beograd, ISI.

Prashad, Vijay. (2007). The Darker Nations: A People's History of the Third World. New York, The New Press.

Rajan, M.S. (1990). The Future of Non-Alignment and the Non-Aligned Movement. New Delhi, Konark Publishers.

Rakove, Robert B. (2013) Kennedy, Johnson, and the Nonaligned World. Cambridge, Cambridge University Press.

Singham, A.W. Hume, Shirley. (1986) Non-Alignment in an Age of Alignments. London, Zed Books.

Srivastava, Renu. (1995). India and the Nonaligned Summits: Belgrade to Jakarta. New Delhi: Northern Book Centre.

Tadić, Bojana. (1976). Nesvrstanost u teoriji i praksi međunarodnih odnosa. Beograd, IMPP. 
The National Archives (TNA), Foreign and Commonwealth Office (FCO). Venn, Fiona. (2002). The Oil Crisis. London, Pearson Education.

Westad, Odd Arne. (2005). The Global Cold War: Third World Interventions and the Making of Our Times. Cambridge, Cambridge University Press. 